\title{
MAXIMIZING PROMOTION MIX IN SHARIA BANKING TO INCREASE CUSTOMER'S DECISION-TO-SAVE
}

\author{
Mei Vita Hasti Liana ${ }^{1}$, Rosana Eri Puspita ${ }^{2}$, Mochlasin ${ }^{3}$ \\ Institut Agama Islam Negeri Salatiga ${ }^{1,2,3}$

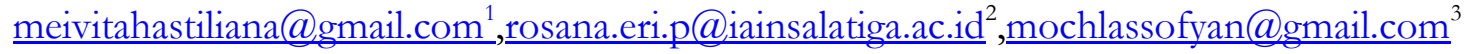

\begin{abstract}
This study aims to determine the effect of the promotion mix on the customer's decision to save. This study uses quantitative methods by processing primary data. Data collection techniques by distributing questionnaires given to customers of Bank Syariah Indonesia in Central Java. Samples were taken as many as 96 respondents with non-probability sampling technique. The data obtained were then processed using the SPSS 25 analysis tool. The results showed that advertising partially had a significant negative effect on customer decisions, while sales promotion, personal selling, direct marketing, and public relations variables partially had a significant positive effect on customer decisions. Together or simultaneously there is an influence between advertising, sales promotion, personal selling, direct marketing, and public relations on the customer's decision to save in Bank Syariah Indonesia (BSI). Researchers hope that BSI can improve promotional strategies, especially in advertising so that it is packaged as attractively as possible so that customers get more complete information, are interested, and then decide to become customers of Bank Syariah Indonesia.
\end{abstract}

Keywords:Promotional mix, Advertising, Sales Promotion, Personal Selling, Direct Marketing, Public Relations, Customer Decision.

\section{INTRODUCTION}

Data innovation is increasingly advanced and extraordinary. It has gone through all sorts of changes, updates, and upgrades very quickly. This makes business competition in the global market more competitive. The number of new competitors that have sprung up in the same industry, makes this a threat for several companies that are starting and also running their business. One of them is the economic players in Indonesia. So that service companies, especially in the banking industry, should pay attention to the products and services they provide to consumers so that there is variety in the market.

Banking amplification in Indonesia is escalating rapidly every year. Along with the improvement in the financial business in Indonesia, Islamic finance continues to compete to increase the number of customers and consumer loyalty. Islamic banking was established due to the desire of Muslims to avoid the form of usury found in most conventional banking. In 
muamalah activities, Muslims want to obtain physical and spiritual prosperity using muamalah and want to enjoy products or services that are under Islamic law.

To win the competition in this era of globalization, it is very necessary to evaluate more creative and innovative business strategies to maintain and increase the number of customers. Some strategies that can be done are by implementing a creative, structured, and well-planned promotional mix to create good communication that occurs between consumers and producers so that the company can retain old customers and attract new customers to get customer satisfaction. The satisfaction obtained by customers leads to decisions that will be made by customers in using the product or conducting transactions in banking. And this is what will make customers be more loyal to banking companies.

In terms of product marketing, promotional activities should be well managed and more targeted development carried out. Promotions are used by companies to attract customers to make decisions to save and use banking products. Promotion is a type of communication to provide information that convinces customers about goods and services in banking (Bukhori, 2007).

Promotional activities are one type of communication that can be carried out by companies and are considered very effective. Promotion is one of several elements contained in the popular marketing mix of other elements and is very influential on customer decisions. The effectiveness of promotion is highly dependent and influenced by how the company chooses the form of promotion for the products marketed in the promotional mix.

A promotional mix is a combination of non-personal communication as well as personal communication that is carried out to provide information about the value of consumers persuasively and is expected to build relationships with customers over a certain period. Included in the dimensions of the promotion mix include advertising, sales promotion, personal selling, direct marketing, and public relations (Donnelly, 2007).

Advertising is a form of promotion that can be run by companies to convey interesting information so that it can influence prospective customers in making decisions (Jakfar, 2003). Personal selling is a communication made by meeting directly between producers and prospective customers to introduce products that will form an understanding of a product so that prospective customers will respond by giving a decision to try or buy the product (Tjiptono, 2008). In terms of banking, it means that the response given by the prospective customer is to decide to become a customer. Direct marketing is a form of interactive marketing, by utilizing advertising media to get a clear response from customers (Tjiptono, 2008). Public relation is an effort that can be carried out by a company in a planned manner (Nova, 2009). 
Liana et al. Maximizing Promotion Mix in Sharia Banking

In previous research, it was stated that the promotion mix partially had a significant impact on customer decisions to make purchases (F. Tambunan, 2020). In another study, it was also explained that the strategy carried out by implementing the promotion mix had a significant influence on saving decisions by customers (Muhlisoh, 2020). The study conducted by the previous researcher also explained that the elements of advertising, promotion, and personal selling influence customers' choices to save. Meanwhile, the elements of public relations and direct marketing do not affect the decision to save (Fauzan, 2019).

Central Java is a province in Indonesia, located in the middle of Java Island. The total area of the island of Java alone is around $32800.69 \mathrm{~km}^{2}$ or roughly about $28.94 \%$ of the total area of the island of Java. In 2020, according to the Central Statistics Agency, the population of Central Java Province is $34,718,204$ people. For its demographics, the majority of people living on the island of Java are Muslims around $96.592 \%$ and the remaining 3.408\% adhere to other religions. With the large number of people embracing Islam in Central Java, it turns out that there are still a few people in Central Java who decide to save in Islamic banking. This can be proven by the number of people who decide to save in conventional banking. Another thing that can be used as evidence is seen from the frequency of the number of conventional bank ATM networks that are everywhere and conventional bank ATM visitors who are always crowded, even though the number of Islamic banking in Central Java province is not small. Bank Syariah Indonesia is a merger of Bank Syariah Mandiri, BNI Syariah, and BRI Syariah. Then the consolidation of Islamic banks determined the name of the combined company to be PT Bank Syariah Indonesia Tbk which was inaugurated through a permit from the OJK with Number SR-3/PB.1/2021 and also inaugurated by President Jokowi. Bank Syariah Indonesia is predicted to be able to improve the Islamic financial market in Indonesia in the eyes of the world. Bank Syariah Indonesia has started operating since it was first launched on February 1, 2021. Bank Syariah Indonesia, led by HeryGunardi, has total assets of Bank Syariah Indonesia until December 2020 which is estimated at around Rp. 214.6 trillion, core capital of more than Rp. 22, 60 trillion, total Third Party Funds reached Rp 210 trillion, and total financing was Rp 157 trillion. When totaled from the number of offices owned by Bank Syariah Mandiri, BNI Syariah, and BRI Syariah, Bank Syariah Indonesia will be supported by more than 1,100 Branch Offices and around 200,741 ATM networks spread across Indonesia.

Based on the background, factors, and a large number of Indonesian Islamic Banks that have been described above, so that researchers are interested in examining which variables affect customers' saving decisions at BSI, with the variable to be tested is the promotion mix which 
includes advertising, promotion sales, personal selling, direct marketing, and public relations. The research framework used by the authors in this study are:

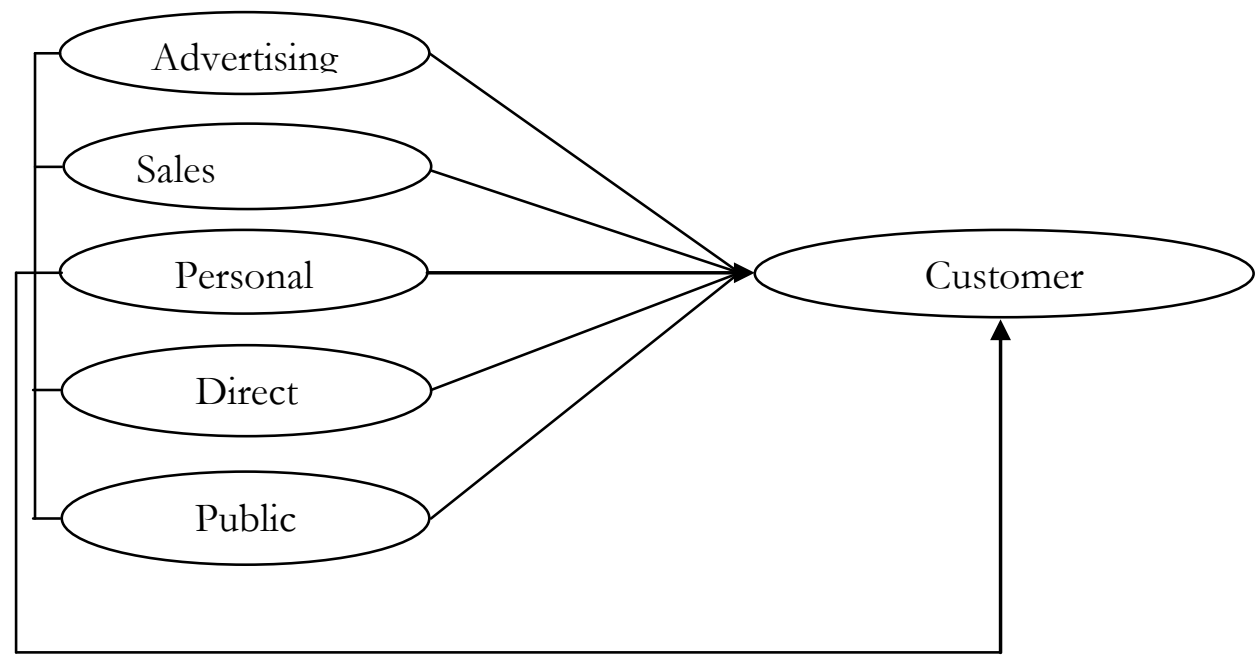

Figure 1. Research Framework

Framework research above, explaining that advertising $\left(\mathrm{X}_{1}\right)$, sales promotion $\left(\mathrm{X}_{2}\right)$, private sales $\left(\mathrm{X}_{3}\right)$, direct marketing $\left(\mathrm{X}_{4}\right)$, and public relations $\left(\mathrm{X}_{5}\right)$, partially and together affect the customer's decision $(\mathrm{Y})$.

\section{METHODOLOGY}

The source of information used in this study is primary data. Primary data is a collection of facts used by analysts with data collection methods in the form of questionnaires to directly classify information in response to questions and examination targets found in the investigation. The list of questions is distributed to the respondents so that they can be filled in according to the wishes of the respondents, then given back to the researchers so that they can be processed.

The population is the entire individual with a certain characteristic, complete, and clear content to be studied. All objects with characteristics that have been determined by the researcher will be taken as samples or represent the population. The population in this study are Indonesian Islamic Bank customers who are in Central Java. While the sample is a component of the entire population obtained in a certain way, has specificity, clarity, and completeness, and can represent the entire population. To determine the sample size in this study, a technique was used non-probability sampling, i.e. only objects according to the criteria that could be sampled, so that this would not leave an opportunity or similar choice to each element of the population to be sampled. This is because the population is in a broad scope so it is considered too much. It is difficult to know with certainty the total number of samples, namely customers who decide to 
save at Indonesian Islamic Banks in Central Java (Wibisono, 2003). This is the formula that is used to decide the sample size:

$$
n=\left(\frac{Z \alpha / 2^{\sigma}}{e}\right)^{2}=\left(\frac{(1,96) \cdot(0,25)}{0,05}\right)^{2}=96
$$

$\mathrm{n}=$ Number of samples

$\mathrm{Z} \alpha=0.05$ then $\mathrm{Z} 0.05=1.96$

$\sigma=$ Population standard deviation $(25 \%)$

$\mathrm{e}=$ Error rate $(5 \%)$

Based on the description above, the sample contained in this research comes from customers of Bank Syariah Indonesia who have suitable characters in this study with the number of respondents who want to be studied is 96 people. An assessment is said to be feasible if it has as many as 30 to 500 respondents. So that this amount is already included in the criteria for research (Sugiyono, 2011). The type of research in this study was carried out by applying a quantitative strategy. The first step in this study is hypothesis development. The first hypothesis is talking about the influence of BSI advertising on customer decisions.

There have been many studies examining the effect of the promotion mix on customer decisions. The first variable in the promotion mix is advertising. Advertising is a message that is carried out through various media to offer products to the public (Rena, 2013). Advertising throughmedia websites has a very strong influence on customer decisions. However, the influence of advertising media such as advertisements through TV media, advertisements through magazine media, and advertisements through newspaper media influences customer decisions (Gunawan, 2011). Thus, the following hypothesis is formulated:

$H_{1}$ : There is a positive and significant influence between advertising on customer decisions to save at BSI.

In the second variable, there is a sales promotion which is a form of offer that encourages consumers to take a certain action at a certain time (Timmy, 2016). Sales promotion using shortterm incentives that encourage product purchases (Kotler \& Amstrong, 2008). A competitive business company must promote as well as possible, otherwise, the company may lose its market share without advertising (Manullang, 2008). Thus, the following hypothesis is formulated: $H_{2}$ : There is a positive and significant influence between sales promotions on customers' decisions to save at BSI.

In previous research that has been done, the third variable, namely personal selling, is a conversation with prospective buyers to create sales (Irawan, 2003). Personal selling by visiting the customer's house, the salesperson meeting directly with the prospective customer at the 
office, or using the services of an agent is an easy way and can influence the decisions of prospective customers (Fauzan, 2019). Therefore, the following hypothesis is formulated: $H_{3}$ : There is a positive and significant effect between personal selling on customers' decisions to save at BSI.

Previous research also explained that direct marketing is interactive marketing by using several advertising media to get a response from consumers (Hasan, 2008). Direct marketing using media that are directly related to customers is better able to provide information to potential customers about products (Fauzan, 2019). Thus, the following hypothesis was formulated:

$H_{4}$ : There is a positive and significant influence between direct marketing on customer decisions to save at BSI.

The research that has been done explains that public relations have a big impact on the public. Public relations by carrying out social service activities, speeches, seminars, or open discussions will indirectly create a good image in the eyes of customers so that customers believe and make a decision (Fauzan, 2019). Providing product socialization, conducting or participating in exhibitions, holding recitations will provide references and also information to customers to make decisions. Thus, the following hypothesis was developed:

$H_{5}$ : There is a positive and significant relationship between the community's relationship to the customer's decision to save at BSI.

Previous research explainedthat the promotion mix is the best and most strategic combination of advertising variables, personal selling, and other promotional tools that are arranged to achieve the goals expected by the company (Irawan, 2003). An appropriate promotion mix will be able to improve customer decisions so that the goals of a company or organization can be achieved. Thus, the following hypothesis is formulated:

$H_{6}$ : There is a positive and significant influence between the promotion mix on the customer's decision to save at Bank Syariah Indonesia.

In the data analysis used in this study, there are several steps. The first step is the validity test which is carried out by connecting the bagged item scores on each statement contained in the questionnaire with the entire score of each variable (Ghozali, 2013). The second step, the reliability test which is usually used to examine the level of reliable trust in a research instrument (Walukow, 2014). This is done if an instrument in the study has been tested and its validity recognized, because if the instrument of research is not said to be valid, then there is no need to continue to do reliability testing. The third step, the classical assumption test, the coefficient of determination test, is used to determine whether there is an influence between the independent variables on the dependent variable using the T-test and the F-test. Based on the research that 
Liana et al. Maximizing Promotion Mix in Sharia Banking

has been done, data processing that has been carried out using SPSS 25, the results of the validity test presented in Table1.

Table 1. Validity Test Results

\begin{tabular}{|c|c|c|c|c|}
\hline Variable & Item & r-count & r-table & Descriptions \\
\hline \multirow[t]{4}{*}{ Advertising } & Item 1 & 0.680 & 0.202 & Valid \\
\hline & Item 2 & 0.708 & 0.202 & Valid \\
\hline & Item 3 & 0.462 & 0.202 & Valid \\
\hline & Item 4 & 0.557 & 0.202 & Valid \\
\hline \multirow[t]{4}{*}{ Sales Promotion } & Item 1 & 0.439 & 0.202 & Valid \\
\hline & Item 2 & 0.416 & 0.202 & Valid \\
\hline & Item 3 & 0.708 & 0.202 & Valid \\
\hline & Item 4 & 0.445 & 0.202 & Valid \\
\hline \multirow[t]{4}{*}{ Personal selling } & Item 1 & 0.680 & 0.202 & Valid \\
\hline & Item 2 & 0.676 & 0.202 & Valid \\
\hline & Item 3 & 0.488 & 0.202 & Valid \\
\hline & Item 4 & 0.708 & 0.202 & Valid \\
\hline \multirow[t]{4}{*}{ Direct Marketing } & Item 1 & 0.438 & 0.202 & Valid \\
\hline & Item 2 & 0.322 & 0.202 & Valid \\
\hline & Item 3 & 0.538 & 0.202 & Valid \\
\hline & Item 4 & .493 & 0.202 & Valid \\
\hline \multirow[t]{4}{*}{ Public Relations } & Butri 1 & 0.547 & 0.202 & Valid \\
\hline & Item 2 & 0.597 & 0.202 & Valid \\
\hline & Item 3 & 0.493 & 0.202 & Valid \\
\hline & Item 4 & 0.438 & 0.202 & Valid \\
\hline \multirow[t]{4}{*}{ Decisions } & Item 1 & 0.505 & 0.202 & Valid \\
\hline & Item 2 & 0.522 & 0.202 & Valid \\
\hline & Item 3 & 0.438 & 0.202 & Valid \\
\hline & Item 4 & 0.440 & 0.202 & Valid \\
\hline
\end{tabular}

Source: primary data processed, 2020

From table 1 it is known that the value of $\mathrm{r}$ count for each question item $>\mathrm{r}$ table $(0.202)$. This means that the data is said to be valid or worthy of being used as a research questionnaire. Based on the research that has been done, data processing that has been carried out using SPSS 25 , the results of the reliability test are as follows:

Table 2. Results of Reliability Test

\begin{tabular}{lcc}
\hline \multicolumn{1}{c}{ Variable } & Cronbach's Alpha & Descriptions \\
\hline Advertising & 0.935 & Reliable \\
Sales Promotion & 0.936 & Reliable \\
Personal Sales & 0.935 & Reliable \\
Direct Marketing & 0.934 & Reliable \\
Public Relations & 0.933 & Reliable \\
Customer Decision & 0.935 & Reliable \\
\hline
\end{tabular}

Source: primary data processed, 2020 
Based on table 2 above, it can be concluded that each variable has a Cronbach's alpha value $>0.70$, which means that all variables in this questionnaire can be said to be reliable.

\section{RESULT AND DISCUSSION}

Based on the research that has been done, the characteristics of the respondents are presented in table 3 .

Table 3 Demographic Information Respondents

\begin{tabular}{ll}
\hline Demographic Gender & Percentage \\
\hline Gender & \\
Male & $60,4 \%$ \\
Female & $39,6 \%$ \\
Age & \\
$16-20$ & $24,0 \%$ \\
$21-25$ & $55,2 \%$ \\
$26-30$ & $13,5 \%$ \\
$31-35$ & $6,3 \%$ \\
$36-40$ & $1,0 \%$ \\
Occupation & \\
Lecturer & $1,0 \%$ \\
Employees & $32,3 \%$ \\
Students & $53,1 \%$ \\
Civil servants & $2,1 \%$ \\
Entrepreneurs & $11,5 \%$ \\
\hline Soure: prmaty
\end{tabular}

Source: primary data processed, 2020

Table 3 shows that the sex of the respondents in this study is male -men are superior as many as 58 people or $60.4 \%$ of the total $100 \%$ of respondents studied, and the remaining 38 people, namely $39.6 \%$ of respondents are women. The table shows that the age of the respondents in this study was dominated by respondents aged 21-25 years as many as 53 people, namely $55.2 \%$ of the total $100 \%$ of respondents researched. In the second position, there are respondents aged 16-20 years as many as 23 people, namely $24.0 \%$. In the third position, there are respondents aged 26-30 years as many as 13 people, namely $13.5 \%$. In the fourth position, there are respondents aged 31-35 years as many as 6 people, namely 6.3\%. And the last position there are respondents aged 36-40 years as many as 1 person, namely $1 \%$. The table shows that the work of the respondents in this study was dominated by 51 students, namely $53.1 \%$ of the total $100 \%$ of respondents studied. The second position who worked as employees were 31 people, namely $32.3 \%$. The third position who works as an entrepreneur is 11 people, namely 
Liana et al. Maximizing Promotion Mix in Sharia Banking

$11.5 \%$. The fourth position worked as civil servants as many as 2 people, namely $2.1 \%$. And the last position there is a respondent who works as a lecturer as much as 1 person, namely $1.0 \%$.

Based on the data processing that has been carried out using SPSS 25, the T-test result is presented in Table 4.

Table 4. T-Test Results

\begin{tabular}{lccc}
\hline \multicolumn{1}{c}{ Variable } & Unstandardized Coefficients (B) & t-calculate & Sig. \\
\hline Advertising & -0.499 & 0.000 & 0.000 \\
Sales Promotion & 0.119 & 0.031 & 0.031 \\
Personal Selling & 0.453 & 0.000 & 0.000 \\
Direct Marketing & 0.434 & 0.002 & 0.002 \\
Public Relations & 0.381 & 3,000 & 0.003 \\
\hline
\end{tabular}

Source: primary data processed, 2020

The meaning of the regression model equation above is a constant value 1.286 which means that when advertising $\left(\mathrm{X}_{1}\right)$, sales promotion $\left(\mathrm{X}_{2}\right)$, personal selling $\left(\mathrm{X}_{3}\right)$, direct marketing $\left(\mathrm{X}_{4}\right)$, public relations $\left(\mathrm{X}_{5}\right)$ constant or non-existent, or equal to 0 , then the customer's decision (Y) will increase by 1.286. Then the regression coefficient value of advertising $\left(\mathrm{X}_{1)}=-0.499\right.$ means that if variable advertising increased by 1, then the decision of customers to save on Sharia Bank Indonesia will decrease by 0.499 . For sales promotion regression coefficient $\left(\mathrm{X}_{2)}=\right.$ 0.119 can be interpreted that if the variable sales promotions increased by 1 , then the decision of customers to save on Sharia Bank Indonesia will also increase by 0.119 . Then the regression coefficient value of personal sales $\left(\mathrm{X}_{3}\right)=0.453$ can be interpreted that if the person selling variable increases by 1 , then the customer's decision to save at Bank Syariah Indonesia will also increase by 0.453 . Furthermore, for direct marketing regression coefficient values $\left(X_{4}\right)=0.434$ can be interpreted that if the variable direct marketing increased by 1 , then the decision of customers to save on Sharia Bank Indonesia will also increase by 0.434 . And for the value of the public relations regression coefficient $\left(\mathrm{X}_{5}\right)=0.381$, it can be interpreted that if the public relations variable increases by 1 , then the customer's decision to save at Bank Syariah Indonesia will also increase by 0.381 .

$\mathrm{T}$ above test results, it can be seen the effect of each independent variable on the dependent variable is the result of testing advertising variables $\left(\mathrm{X}_{1)}\right.$ obtained t value of -4.110 and significant value of 0.000 with a coefficient alpha of $5 \%$. Because the value of sig $<0.05$, advertising has a negative and significant effect on customer decisions $(\mathrm{Y})$. Then for the test results of the sales promotion variable $\left(\mathrm{X}_{2}\right.$ obtained a t-value of 1.522 and a significant value of 
0,031 with a coefficient alpha of $5 \%$. Because the value of sig $<0.05$, then sales promotion has a positive and significant effect on customer decisions $(\mathrm{Y})$. For the test results, the private sales variable $\left(\mathrm{X}_{3)}\right.$ obtained a t-value of 3.810 and 0.000 with a significance value of coefficient alpha $5 \%$. Because the value of sig $<0.05$, personal selling has a positive and significant effect on customer decisions $(\mathrm{Y})$. Then the test results of direct marketing variables $\left(\mathrm{X}_{4}\right)$ obtained $\mathrm{t}$ value of 3.270 and 0.002 with a significance value of coefficient alpha 5\%. Because the value of sig < 0.05 , then direct marketing has a positive and significant effect on customer decisions (Y). And then for the results of testing the public relations variable $\left(\mathrm{X}_{5}\right)$, the $\mathrm{t}$-value is 3,000 and the significance value is 0.003 with an alpha coefficient of $5 \%$. Because the value of sig $<0.05$, public relations has a positive and significant effect on customer decisions $(\mathrm{Y})$.

Table 5 F-Test Results

\begin{tabular}{ccc}
\hline Model & F-Calculate & Sig. \\
\hline Reggression & 41.260 & $0.000^{\mathrm{b}}$ \\
\hline
\end{tabular}

Source: primary data processed, 2020

Based on the results of the $\mathrm{F}$ test in table 5 above, the significance value is $0.000<0.05$, which means that the independent variables consist of advertising, sales promotion, personal selling, direct marketing, and relationships The community simultaneously has a significant influence on the dependent variable, namely customer decisions.

Table 6. Results of Determination Coefficient

\begin{tabular}{ccccc}
\hline Model & $\mathbf{R}$ & $\mathbf{R}^{2}$ & Adjusted $\mathbf{R}^{2}$ & Std. Error of the Estimate \\
\hline $\mathbf{1}$ & $0834^{\mathrm{a}}$ & 0696 & 0679 & 1309 \\
\hline
\end{tabular}

Source: primary data processed, 2020

Based on table 6 above, it can be seen that the magnitude of adjusted the $\mathrm{R}^{2}$ is 0.679 . This means that $67.9 \%(0.679 \times 100 \%)$ of the dependent variable in the form of customer decisions can be explained by all independent variables in this study, namely advertising, sales promotion, personal selling, direct marketing, public relations. While the remaining $32.1 \%$ is influenced by other variables not included in this study.

The results of hypothesis testing in this study are the effect of advertising (X1) on customer decisions to save at Bank Syariah Indonesia in this study, the value of the t-test results is -4.110 and the significance value is 0.000 less than 0.05 . This shows that the advertising 
variable has a negative and significant effect on customer decisions, so $\mathrm{H} 1$ is rejected. This means that the advertising carried out by the company does not have a significant influence on the customer's decision to save at Bank Syariah Indonesia. The results of this study are in line with previous research which states that the advertising variable has no significant and significant effect on customer decisions (Kaluku, 2018). This study is also following other previous studies which state that advertising does not have a positive and significant effect on customer decisions to save at Bank Syariah Indonesia (Darna, 2013). This shows that the advertising carried out by the company through print media, internet media, electronic media, and also brochure media is less precise and less able to reach and attract customers, which means that advertising variables cannot make customers decide to save at Bank Syariah Indonesia.

The effect of sales promotion (X2) on customer decisions to save at Bank Syariah Indonesia in this study, the value of the t-test results is 1.522 and a significance value of 0.031 is less than 0.05 . This shows that the sales promotion variable has a positive and significant effect on customer decisions, so $\mathrm{H} 2$ is accepted. This means that the more attractive the sales promotion carried out by the company, the greater the customer's decision to save at Bank Syariah Indonesia. The results of this study are in line with previous research which states that sales promotions have a positive and significant effect on customer decisions to save at Bank Syariah Indonesia (Fauzan \& Bachdim, 2019). This is also under previous research which states that sales promotion variables have a positive and significant influence on customer decisions (Muhlisoh, 2020). Under the indicators that have been compiled in this study, namely sales promotions by providing price discounts, giving gifts, providing low admin fees, and also providing relief for making initial deposits to customers and prospective customers to increase interest in existing products, so that customers can make decisions to save at Bank Syariah Indonesia.

The effect of personal selling (X3) on the customer's decision to save at Bank Syariah Indonesia in this study, the value of the t-test results is 3.810 and the significance value is 0.000 less than 0.05 . This shows that the personal selling variable has a positive and significant effect on customer decisions, so $\mathrm{H} 3$ is accepted. This means that the more effective the sales force in providing information and building relationships with customers, the more customers will increase their decision to save at Bank Syariah Indonesia. The results of this study are under previous research which states that personal selling has a positive and significant effect on customer decisions to save at Bank Syariah Indonesia (Kaluku, 2018). This is also in line with previous research which states that personal selling has a positive effect on consumer decisions (Junaida, 2019). This means that the communication made by salespeople with prospective 
customers can form an understanding to customers about the products offered so that they are interested and decide to save at Bank Syariah Indonesia.

The effect of direct marketing (X4) on the customer's decision to save at Bank Syariah Indonesia in this study, the value of the t-test result is 3.270 and the significance value is 0.002 less than 0.05. This shows that the direct marketing variable has a positive and significant effect on customer decisions, so $\mathrm{H} 4$ is accepted. This means that the more effective and professional the direct marketing is carried out by the salesperson, the greater the customer's decision to save at Bank Syariah Indonesia. The results of this study are under previous research which states that direct marketing has a positive and significant effect on customer decisions to save at Bank Syariah Indonesia (Kaluku, 2018). This is also in line with previous research which states that direct marketing has a positive and significant effect on consumer decisions (Junaida, 2019). This means that the research indicators used by researchers, namely direct marketing through mail, telemarketing media, SMS media, and also social media can provide information and understanding for customers and prospective customers of Bank Syariah Indonesia.

The effect of public relations (X5) on the customer's decision to save at Bank Syariah Indonesia in this study, the value of the t-test results is 3,000 and a significance value of 0.003 is less than 0.05 . This shows that the public relations variable has a positive and significant effect on customer decisions, so H5 is accepted. This shows that the better the relationship built by the company with the community, the higher the customer's decision to save at Bank Syariah Indonesia. The results of this study are under previous research which stated that public relations had a positive and significant effect on customer decisions to save at Bank Syariah Indonesia (Tambunan, 2020). This means that the participation of Bank Syariah Indonesia in activities that are directly related to the community such as social and community activities can improve the product image, leave a positive impression, and can also strengthen the relationship of Bank Syariah Indonesia to customers and prospective customers.

The effect of advertising (X1), sales promotion (X2), personal selling (X3), direct marketing (X4), public relations (X5), on customer decisions ( $Y$ ) in this study, the results of the calculated $F$ test showed 41.260 with a significance value 0.000 with a significance probability value of less than 0.05 , the correlation coefficient value of 0.834 . So it can be concluded that together the promotional mix variables consisting of advertising, sales promotion, personal selling, direct marketing, and public relations have a positive and significant effect on customer decisions, so H6 is accepted. This shows that the better the promotion mix strategy carried out by the company, the greater the customer's decision to save at Bank Syariah Indonesia. The results of this study are following previous research which states that the promotional mix 
Liana et al. Maximizing Promotion Mix in Sharia Banking

consisting of advertising, sales promotion, personal selling, direct marketing, and public relations has a positive and significant effect on customer decisions to save at Bank Syariah Indonesia (Fauzan, 2019). This means that if the promotion mix is jointly carried out properly and well, it will be able to attract customers' attention and influence customers in making a decision (Tambunan, 2020). If the promotion mix strategy is implemented correctly, the number of Bank Syariah Indonesia customers may increase.

\section{CONCLUSION}

Based on the results of research that has been done by researchers, several conclusions can be drawn, namely, the advertising variable has a negative and significant effect on customer decisions. That means that high advertising will not necessarily improve customer decisions. Meanwhile, the variables of sales promotion, personal selling, direct marketing, and public relations have a positive and significant effect on customer decisions. Simultaneously, the variables of advertising, sales promotion, personal selling, direct marketing, and public relations have a positive and significant effect on customer decisions. That means that a high promotion mix will increase customer decisions to save at Bank Syariah Indonesia.

Researchers hope that further researchers who will examine similar variables are expected to add other variables that have not been studied in this study, such as variables related to decisions. Thus, future researchers can provide better results.Furthermore, the researcher hopes that Bank Syariah Indonesia can improve promotional strategies, especially in advertising so that it is packaged as attractively as possible so that customers get more complete information, are interested, and then decide to become customers of Bank Syariah Indonesia.

\section{REFERENCES}

Bukhori, A. (2007). Manajemen Pemasaran dan Pemasaran Jasa. Alfa Beta.

Darna, D. P. (2013). Pengaruh Bauran Promosi Terhadap Keputusan Pengambilan Produk Pembiayaan KPR Platinum iB Pada Bank X Syariah Cabang Harmoni -Jakarta. Jurnal Ekonomi Dan Bisnis.

Donnelly. (2007). Marketing Management: Knowledge and Skills. McGraw-Hill.

Erni Junaida, N. H. (2019). Pengaruh Bauran Promosi Terhadap Keputusan Pembelian Perumahan. Jurnal Manajemen Dan Kenangan.

Fauzan, M., \& Bachdim, U. (2019). Pengaruh Bauran Promosi Terhadap Keputusan Nasabah Dalam Menggunakan Tabungan ib Hasanah Pada PT BNI Syariah Cabang Palu. Jurnal Perbsnkan Dan Keuangan Syariah. 
Ghozali, I. (2013). Aplikasi Analisis Multivariate dengan Program IBM SPSS 21. Badan Penerbit Universitas Diponegoro.

Gunawan, A. E. (2011). Pengaruh Media Iklan Terhadap Pengambilan Keputusan Pembelian Konsumen Pada Sepeda Motor Honda. E-Journal UAJY.

Hasan, A. (2008). Marketing. Penerbit Media Utama.

Irawan, B. S. (2003). Manajemen Pemasaran Modern. Liberty Offset.

Jakfar, K. (2003). Studi Kelayakan Bisnis Edisi Revisi. Kencana.

Kaluku, F. (2018). Analisis Bauran Promosi Terhadap Keputusan Nasabah Menggunakan Produk Unggulan Pada Bank Syariah Mandiri Cabang Manado. Jurnal EMBA.

Kotler, \& Amstrong. (2008). Prinsip-Prinsip Pemasaran. Erlangga.

Manullang. (2008). Dasar-Dasar Manajemen. Ghalia Indonesia.

Muhlisoh, L. (2020). Pengaruh Bauran Promosi Terhadap Keputusan Nasabah Dalam Memilih Produk Pembiayaan. Al Maal : Journal of Islamic Economics and Banking, 2.

Muhlisoh, L., Nawawi, K., \& Arif, S. (2020). Pengarub Bauran Promosi Terbadap Keputusan Nasabah Dalam Memilib Produk Pembiayaan.

Nova, F. (2009). Crisis Public Relation (Bagaimana PR Menangani Krisis Perusahaan). Grasindo.

Rena, K. (2013). Manajemen Periklanan dan Aplikasinya di Indonesia. PT Pustaka Utama Grafis.

Sugiyono. (2011). Metode Penelitian Kuantitatif, Kualitatif, dan R\&D. Alfa Beta.

Tambunan, F. (2020). Pengaruh Bauran Promosi dan E-commerce Terhadap Keputusan Pembelian Dengan Kepuasan Sebagai Variabel Intervening. Student Online, 1.

Tambunan, T. S. (2020). Pengaruh Perilaku Konsumen Terhadap Keputusan Pemilihan Penggunaan KWH Meter Listrik Pascabayar dan Prabayar Pada PT PLN (Persero) Ranting Pancur Batu. Jumal Nasional Manajemen Pemasaran \& SDM.

Timmy, W. (2016). Pengaruh Promosi Penjualan dan Periklanan Terhadap Keputusan Pembelian Pada Tabungan Simpedes. Jurnal Advance.

Tjiptono. (2008). Pemasaran Strategik. Penerbit Andi.

Walukow, Sepang, \& Maneke. (2014). Pengaruh Kualitas Produk, Harga, Promosi, dan Lokasi Terhadap Keputusan Pembelian Konsumen di Bentenan Center Sonder Minahasa. Jurnal $E M B A$.

Wibisono. (2003). Riset Bisnis. PT Gramedia Pustaka Utama. 